\title{
PENGARUH UKURAN PARTIKEL BERAS HITAM (Oryza sativa L.) TERHADAP RENDEMEN EKSTRAK DAN KANDUNGAN TOTAL ANTOSIANIN
}

\section{THE INFLUENCE OF PARTICLE SIZE OF BLACK RICE (Oryza sativa L.) ON EXTRACT YIELD AND TOTAL ANTHOCYANIN CONTENT}

\author{
Ria Maulida, Any Guntarti ${ }^{1}$ \\ ${ }^{1}$ Fakultas Farmasi Universitas Ahmad Dahlan \\ Jl. Prof. Dr. Soepomo, Janturan, Yogyakarta Telp. (0274) 379418 \\ Email: any_guntarti@yahoo.co.id
}

\begin{abstract}
ABSTRAK
Beras hitam telah teruji memiliki kandungan antosianin yang cukup tinggi. Beras hitam dapat menjadi sumber antosianin yang potensial jika penyarian antosianinnya optimal. Ukuran partikel simplisia merupakan salah satu faktor yang berpengaruh terhadap jumlah zat aktif yang tersari pada proses maserasi. Pengecilan ukuran partikel simplisia dapat meningkatkan jumlah zat aktif yang tersari dan jumlah rendemen ekstrak. Nilai rendemen yang tinggi menunjukkan proses ekstraksi zat aktif berlangsung efektif. Penelitian ini dilakukan dengan variasi ukuran partikel pada proses maserasi beras hitam. Tujuannya adalah untuk melihat pengaruh variasi ukuran partikel beras hitam terhadap rendemen ekstrak dan kandungan total antosianin hasil maserasi. Penelitian ini menggunakan sampel beras hitam yang diperoleh dari Pasar Beringharjo, Yogyakarta. Maserasi sampel dengan pelarut etanol 96\% yang ditambah $\mathrm{HCl} 37 \%$ hingga $\mathrm{pH} 1$ (1:6) dilakukan selama 6x24 jam dengan variasi ukuran serbuk beras hitam mesh 20/40, 40/60 dan beras hitam utuh. Analisis data rendemen ekstrak dan kandungan total antosianin menggunakan uji one-way ANOVA dengan taraf kepercayaan 95\%. Hasil penelitian menunjukkan rendemen ekstrak dan kandungan total antosianin beras hitam mesh 20/40, 40/60 dan beras hitam utuh berturut-turut $6 \% ; 16 \% ; 11,26$; dan 30,76 mg/100 g; 1.167,80 $\mathrm{mg} / 100 \mathrm{~g} ; 322,23 \mathrm{mg} / 100 \mathrm{~g}$. Ada perbedaan yang signifikan antar kelompok ukuran partikel $(\mathrm{P}<0,05)$, sehingga dapat disimpulkan bahwa perbedaan ukuran partikel beras hitam mempengaruhi rendemen ekstrak dan kandungan total antosianin hasil maserasi.
\end{abstract}

Kata kunci: ekstrak beras hitam, maserasi, ukuran partikel, rendemen ekstrak, kandungan total antosianin

\begin{abstract}
Black rice has been tested for its high anthocyanin content. Black rice can be one of the potential sources of anthocyanin. Particle size is one of factors which influences amount of isolated biocompound in maceration process. Decreasing particle size can increase the amount of isolated biocompound and extract yield value. The high value of extract yield shows effectiveness of maceration process. In this research, particle size variation has been done maceration process for investigating its influence on black rice extract yield and total anthocyanin content of maceration result. This study used black rice (Oryza sativa L.) from Beringharjo market, Yogyakarta. Maceration with solvent of ethanol 96\% added $\mathrm{HCl} 37 \%$ until $\mathrm{pH} 1,0(1: 6)$ is done for $6 \times 24$ hours, with particle size variation: mesh 20/40, 40/60 and whole bran of black rice. Data of extract yield and total anthocyanin content are analyzed by using one-way ANOVA with confidence level $95 \%$. The results revealed that extract yield and total anthocyanin content of black rice extract with particle size
\end{abstract}


variation: mesh $20 / 40,40 / 60$ and whole bran of black rice intact $6 \% ; 16 \% ; 11,26 \%$; and $30,76 \mathrm{mg} / 100 \mathrm{~g} ; 1167,80 \mathrm{mg} / 100 \mathrm{~g} ; 322,23 \mathrm{mg} / 100 \mathrm{~g}$, respectively. There is significant difference between tested groups $(\mathrm{P}<0,05)$. We concluded that particle size of black rice influences extract yield and total anthocyanin content of maceration result.

Keywords: black rice extract, maceration, particle size, extract yield, total anthocyanin content

\section{PENDAHULUAN}

Antosianin merupakan salah satu senyawa metabolit sekunder yang memiliki banyak kegunaan dan terdapat di banyak jenis tumbuh-tumbuhan. Manfaat antosianin diantaranya sebagai indikator alami $\mathrm{pH}$ (Bondre dkk., 2012), pewarna alami yang biasanya digunakan pada makanan dan minuman (beverage), dan anti kanker (Karaivanova dkk., 1990; Kamei dkk., 1995).

Antosianin juga memiliki aktivitas antioksidan karena merupakan senyawa fenolik yang dapat menangkal radikal bebas. Antioksidan adalah senyawa yang mempunyai struktur molekul yang dapat memberikan elektronnya dengan cuma-cuma kepada molekul radikal bebas tanpa terganggu sama sekali fungsinya dan dapat memutus reaksi berantai dari radikal bebas (Kumalaningsih, 2007).

Antioksidan dapat digunakan di berbagai macam bidang, seperti bidang pangan dan industri famasi, industri tekstil (Bangee dkk., 1995), perminyakan (Pan dkk., 1998 dan Jones dkk. 1997) dan industri karet (Pushpa dkk., 1995). Eksplorasi tanaman yang mengandung antosianin tinggi terus dilakukan. Salah satu tanaman yang mengandung antosianin tinggi adalah beras hitam. Dari penelitian Kristamtini dkk. (2014) diketahui bahwa kadar antosianin dari 11 kultivar padi beras hitam di Indonesia berkisar antara 50-600 mg/100 g. Kandungan antosianin yang tergolong tinggi, hampir sama dengan kandungan dalam 100 gram anggur segar (Wrolstad dan Giusti, 2001).

Penelitian tentang ekstraksi antosianin pada tanaman banyak dilakukan menggunakan metode maserasi. Hasil penelitian sebelumnya (Suzery dkk., 2010) menunjukkan bahwa ekstraksi dengan metode maserasi pada suhu kamar memberikan hasil penyarian antosianin yang lebih tinggi dibanding maserasi pada suhu $5^{\circ} \mathrm{C}$ pada bunga rosella. Hasil maserasi pada suhu kamar juga memberikan hasil yang lebih tinggi dibandingkan dengan metode Soxhlet.

\section{Maserasi (macerase $=$ mengairi,} melunakkan) adalah cara ekstraksi yang paling sederhana yaitu dengan melakukan perendaman terhadap simplisia, dan rendaman tersebut disimpan terlindung dari sinar matahari langsung (untuk mencegah reaksi dengan cahaya dan perubahan warna) dan dikocok kembali. Maserasi pada suhu yang ditinggikan $\left(30-50^{\circ} \mathrm{C}\right)$ disebut digesti. Pada proses ekstraksi terjadi dua fase yaitu fase pembilasan dan fase ekstraksi. Fase pembilasan merupakan fase dimana sel-sel yang rusak atau tidak utuh lagi dari simplisia bersentuhan langsung dengan pelarut sehingga komponen di dalam sel semakin mudah untuk berpindah ke dalam pelarut. Semakin halus serbuk simplisia semakin optimal proses pembilasannya. Fase ekstraksi merupakan fase dimana cairan pelarut menembus membran sel yang masih utuh sehingga terjadi pembengkakan pada sel dan disolusi komponen sel ke cairan pelarut yang berhasil masuk, dengan adanya perbedaan konsentrasi antara pelarut di dalam sel dan di luar sel maka akan terjadi difusi (Voigt, 1995).

Difusi didefinisikan sebagai suatu proses perpindahan massa molekul suatu zat yang dibawa oleh pergerakan molekuler secara acak dan berhubungan dengan adanya perbedaan konsentrasi aliran molekul melalui suatu batas, misalnya membran polimer (Martin dkk., 1993). Ukuran partikel padatan menjadi salah satu faktor yang penting dalam proses ekstraksi. Menurut Purseglove (1981) besar ukuran bahan yang dipakai untuk keperluan ekstraksi adalah 50 mesh dan bahan terhalus adalah ukuran 60 mesh. Penetapan kandungan total antosianin dapat dilakukan dengan metode $\mathrm{pH}$ diferensial (Wrolstad dan Giusti, 2001). Metode ini 
merupakan modifikasi dari metode yang awalnya dilakukan oleh Fuleki dan Francis 1968. Dasar dari metode $\mathrm{pH}$ diferensial adalah sifat antosianin yang dapat mengalami perubahan warna secara reversible seiring dengan perubahan $\mathrm{pH}$. Pada $\mathrm{pH}$ sangat rendah $(\mathrm{pH} 1-2)$ antosianin berada pada bentuk oxonium berwarna (ion flavilium), sedangkan pada $\mathrm{pH}$ 4-5 akan terbentuk senyawa hemiketal yang tidak berwarna. Perubahan struktur dan warna tersebut menimbulkan perubahan absorbansi pada pola spektra yang muncul jika dibaca dengan spektrofotometer visibel (Wrolstad dan Giusti, 2001).

\section{METODE PENELITIAN}

\section{Bahan Penelitian}

Bahan yang digunakan adalah beras hitam (Oryza sativa L.) dari Pasar Beringharjo Yogyakarta, etanol 96\%, $\mathrm{HCl} 37 \%, \mathrm{KCl}$, Natrium asetat, $\mathrm{NaOH}$, etanol dan ammonia. Semua bahan yang digunakan berskala pro analisis, E.Merck.

\section{Jalannya Penelitian}

\section{Pembuatan serbuk beras hitam}

Beras hitam dicuci, dikeringkan dengan oven pada suhu $50^{\circ} \mathrm{C}$. Beras hitam diserbuk menggunakan blender. Serbuk kemudian diayak menggunakan sieving machine dengan ayakan mesh 20/40 dan 40/60 hingga didapatkan serbuk dengan ukuran yang sesuai dan seragam. Selanjutnya serbuk disimpan di tempat yang kering, tertutup rapat dan terlindung dari cahaya matahari, dan siap untuk diekstraksi.

\section{Pembuatan ekstrak beras hitam}

Beras hitam dengan masing-masing ukuran partikel serbuk dan beras hitam utuh ditimbang sebanyak 100 gram lalu dimaserasi dengan etanol $96 \%$ yang diasamkan dengan $\mathrm{HCl}$ $37 \%$ hingga pH 1,0 sebanyak $600 \mathrm{ml}$ (1:6). Beras hitam dan pelarut diaduk menggunakan stirrer dengan kecepatan $300 \mathrm{rpm}$ selama 4 jam kemudian didiamkan hingga 24 jam di tempat gelap dan dibungkus aluminium foil. Setelah 24 jam, maserat disaring dengan corong butchner untuk memisahkan filtrat dan ampas. Maserat ditimbang dan dihitung rendemen ekstraknya.

3. Uji kualitatif flavonoid: Uji flavonoid dengan uap ammonia (Robinson, 1995).
4. Uji antosianin: Dengan uji tabung antosianin dengan $\mathrm{HCl}$ dan $\mathrm{NaOH}$ (Harborne, 1987).

5. Uji spektrum: Dengan spektrofotometri visibel dalam pelarut methanol-HCl 1\%(Harbone, 1987).

\section{Penetapan kandungan total antosianin} dengan metode $\mathbf{p H}$ diferensial (Giusti and Wrolstad, 2001): Ekstrak ditimbang sebanyak $500 \mathrm{mg}$, dilarutkan dalam $25 \mathrm{ml}$ etanolpa yang sudah diasamkan hingga $\mathrm{pH}$ 1,0. Sebanyak 1,0 $\mathrm{ml}$ larutan ekstrak dimasukkan masing-masing dalam 2 labu takar 10,0 ml. Labu takar 1 ditambahkan larutan buffer $\mathrm{KCl} \mathrm{pH}$ 1,0 dan labu takar 2 ditambahkan larutan buffer natrium asetat pH 4,5 sampai batas tanda, gojok hingga larut. Larutan didiamkan selama 30-1 jam (operating time). Masing-masing larutan diukur absorbansinya pada panjang gelombang serapan maksimal dan $700 \mathrm{~nm}$ dengan blangko pelarut etanol p.a, buffer $\mathrm{KCl}$ dan natrium asetat.

Rendemen ekstrak dihitung dengan rumus:

Rendemen $(\%)=\frac{\text { Bobot ekstrak }}{\text { Bobot simplisia kering }} \times 100 \%$

Perhitungan absorbansi larutan sampel (A) dengan perhitungan sebagai berikut:

$\mathrm{A}=\left(\mathrm{A}_{\mathrm{vis}-\mathrm{max}}-\mathrm{A}_{700}\right)_{\mathrm{pH} \mathrm{1,0}}-\left(\mathrm{A}_{\mathrm{vis}-\mathrm{max}}-\mathrm{A}_{700}\right)_{\mathrm{pH} 4,5}$

Konsentrasi antosianin $(\mathrm{mg} / 100 \mathrm{~g})=$

$$
\frac{A x M W x D F x V x 100}{\text { sxixW }}
$$

Dimana:

A = absorbansi sampel.

MW = berat molekul dihitung sebagai sianidin-

3-glukosida $\quad(M W=449,2)$

$\mathrm{DF}=$ faktor kelarutan

$\mathrm{V} \quad=$ volume larutan induk sampel

$\mathrm{W}=$ berat ekstrak sampel

$\varepsilon=($ adsorptivitas molar sianidin-3-glukosida) $=26.900$ dan 100 merupakan faktor konversi untuk perhitungan dalam $\mathrm{mg} / 100$ gram sampel. 


\section{HASIL DAN PEMBAHASAN}

\section{Rendemen ekstrak}

Hasil analisis dengan SPSS dengan taraf kepercayaan $95 \%$ menunjukkan adanya perbedaan yang signifikan antara rendemen ekstrak beras hitam utuh, beras hitam serbuk mesh 20/40 dan beras hitam mesh 40/60. Ukuran patikel beras hitam mesh 40/60 memiliki rendemen ekstrak paling tinggi dibanding beras utuh dan mesh 20/40.
Ukuran partikel mesh 40/60 merupakan ukuran partikel paling kecil dari kelompok percobaan dan memiliki luas permukaan kontak paling luas. Permukaan kontak serbuk simplisia dengan pelarut yang luas akan memaksimalkan kesempatan pelarut untuk mengekstraksi antosianin. Antosianin yang banyak tersari akan meningkatkan nilai rendemen. Nilai rata-rata rendemen ekstrak (\%) beras hitam dengan berbagai ukuran partikel dapat dilihat pada Gambar 1.

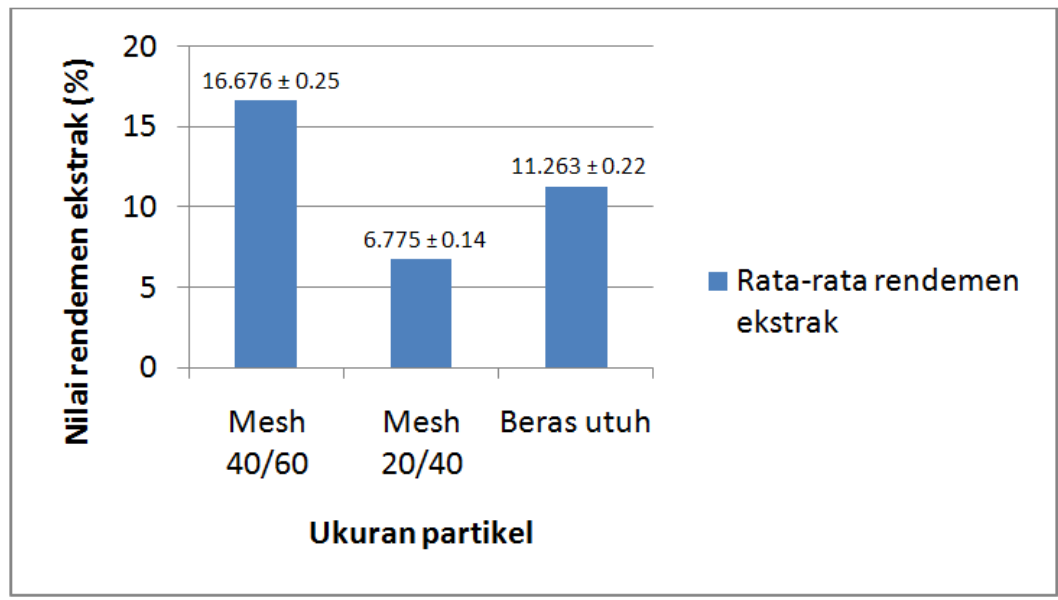

Gambar 1. Nilai rata-rata rendemen ekstrak beras hitam dengan berbagai macam ukuran partikel

Tabel I. Hasil uji flavonoid ekstrak beras hitam menunjukkan hasil positif antosianin

\begin{tabular}{|c|c|c|c|}
\hline Sampel & $\begin{array}{c}\text { Sebelum diuapi } \\
\text { amoniak }\end{array}$ & $\begin{array}{c}\text { Sesudah diuapi } \\
\text { amoniak }\end{array}$ & Kesimpulan \\
\hline Utuh & & & $\begin{array}{c}+ \\
\text { (Warna berubah dari } \\
\text { merah muda menjadi } \\
\text { keabu-abuan) }\end{array}$ \\
\hline $\begin{array}{l}\text { Serbuk mesh } \\
20 / 40\end{array}$ & & & $\begin{array}{c}+ \\
\text { (Warna berubah dari } \\
\text { merah mudah menjadi } \\
\text { keabuan-biru) }\end{array}$ \\
\hline $\begin{array}{l}\text { Serbuk mesh } \\
\quad 40 / 60\end{array}$ & & & $\begin{array}{l}+ \\
\text { (Warna berubah dari } \\
\text { merah muda menjadi } \\
\text { keabuan-bitu) }\end{array}$ \\
\hline
\end{tabular}




\section{Uji flavonoid}

Uji flavonoid dilakukan untuk mengetahui ada tidaknya senyawa flavonoid pada sampel. Uji ini dilakukan atas dasar struktur senyawa antosianin yang merupakan senyawa golongan flavonoid yang bersifat asam sehingga bereaksi dengan basa ammonia. Flavonoid akan berwarna kuning dan antosianin akan berwarna kelabu-biru jika terkena uap ammonia. Perubahan warna terjadi akibat terbentuknya senyawa kuinoid (Robinson, 1995). Hasil uji flavonoid menunjukkan adanya kandungan antosianin dalam ekstrak, ditunjukkan oleh Tabel I.

\section{Uji tabung antosianin}

Hasil uji tabung antosianin dengan $\mathrm{HCl}$ dan $\mathrm{NaOH}$ menunjukkan hasil positif. Pada $\mathrm{pH}$ asam antosianin akan berada pada bentuk ion flavilium yang berwarna merah dan berganti warna biru-hijau pada keadaan basa. Warna biruhijau disebabkan karena antosianin banyak berada dalam bentuk ion anhidro basa. Reaksi perubahan antosianin pada $\mathrm{pH}$ yang berbeda ditunjukkan oleh Gambar 2 dan uji tabung antosianin disajikan pada Tabel II.
Ion anhidro basa biru<smiles>[R]Oc1cc2c([R])cc(=O)cc-2oc1-c1ccc([O-])cc1</smiles>

pH 8-9
Anhidro basa ungu $\mathrm{AH}$

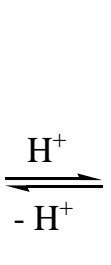<smiles>[R]Oc1cc(=O)cc2oc(-c3ccc(O)cc3)c([R])cc1-2</smiles>

pH 6-8
Ion flavilium merah<smiles></smiles>

pH 1-3

Gambar 2. Perubahan struktur antosianin pada pH yang berbeda (Thompson, 1989)

Tabel II. Hasil uji tabung antosianin menunjukkan hasil positif antosianin

\begin{tabular}{|c|c|c|c|c|}
\hline \multirow[b]{2}{*}{$\underset{1}{\text { Sampe }}$} & \multicolumn{3}{|c|}{ Uji tabung antosianin } & \multirow[b]{2}{*}{ Kesimpulan } \\
\hline & $\begin{array}{c}\text { Sebelum } \\
\text { penambahan } \\
\text { reagen }\end{array}$ & $\begin{array}{c}\text { Sesudah } \\
\text { penambahan } \\
\text { HCl } \\
\end{array}$ & $\begin{array}{c}\text { Sesudah } \\
\text { penambahan } \\
\mathrm{NaOH} \\
\end{array}$ & \\
\hline (utuh) & & 11 & & $\begin{array}{l}\text { (ungu menjadi merah ditambah } \\
\mathrm{HCl} \text { dan menjadi hijau ketika } \\
\text { ditambah } \mathrm{NaOH} \text { ) }\end{array}$ \\
\hline $20 / 40$ & & & & $\begin{array}{l}\text { (ungu menjadi merah ditambah } \\
\mathrm{HCl} \text { dan menjadi hijau ketika } \\
\text { ditambah } \mathrm{NaOH} \text { ) }\end{array}$ \\
\hline $40 / 60$ & & & & $\begin{array}{l}\text { (ungu menjadi merah ditambah } \\
\mathrm{HCl} \text { dan menjadi hijau ketika } \\
\text { ditambah } \mathrm{NaOH} \text { ) }\end{array}$ \\
\hline
\end{tabular}




\section{Uji spektrum tampak metanol-HCl $1 \%$}

Hasil uji spektrum tampak metanol-HCl $1 \%$, diperoleh panjang gelombang serapan maksimal untuk beras hitam utuh, mesh 20/40 dan 40/60 berturut-turut adalah 529,90 nm; $526,30 \mathrm{~nm}$; dan 530,60 $\mathrm{nm}$. Senyawa tersebut merupakan antosianin karena panjang gelombang sampel berada pada rentang panjang gelombang serapan maksimum teoritis antosianin 505-535 nm (Harbone, 1987).

\section{Kandungan total antosianin}

Hasil uji statistik dengan taraf kepercayaan 95\% menunjukkan bahwa ukuran partikelserbuk memberikan pengaruh terhadap kandungan total antosianin yang tersari dalam ekstrak. Nilai rata-rata kandungan total antosianin ekstrak beras hitam dengan berbagai ukuran partikel dapat dilihat pada Gambar 3 . Secara teoritis menurut Heath dan Reineccius (1986), semakin kecil ukuran partikel simplisia semakin luas permukaan spesifiknya, sehingga kontak dengan cairan penyari lebih besar dan penyarian lebih optimal yang ditandai dengan semakin besarnya kadar antosianin dalam ekstrak. Ekstrak beras hitam dengan serbuk mesh 40/60 memiliki kandungan total antosianin yang paling tinggi. Serbuk mesh 40/60 memiliki luas permukaan kontak dengan pelarut yang luas sehingga penyarian antosianinnya besar dan kandungan total antosianin dalam ekstraknya pun besar.

Namun pada penelitian ini kadar antosianin dalam ekstrak mesh 20/40 lebih kecil daripada ekstrak beras hitam utuh. Faktor lain yang kemungkinan berperan besar dalam perbedaan hasil kandungan total antosianin adalah persebaran antosianin dalam beras hitam yang tidak merata di seluruh biji beras hitam dan proses pengecilan ukuran partikel simplisia (Yoshimura dkk., 2012).

Antosianin paling banyak terdapat di pericarp dan aleuron yang merupakan lapisan tipis pada permukaan beras. Pemotongan menggunakan pisau blender yang cepat dan kuat menyebabkan lapisan tipis tersebut hancur lebih cepat dibandingan bagian amilum yang kompak. Lapisan perikarp dan aleurone yang hancur lebih cepat menjadi ukuran partikel serbuk yang kecil, sedangkan bagian pati yang hancur lebih lambat menjadi ukuran partikel yang lebih besar. Perbedaan persebaran antosianin dalam serbuk simplisia tersebut menyebabkan hasil maserasi 100 gram serbuk beras hitam dengan ukuran mesh 40/60 menghasilkan kandungan total antosianin dalam ekstrak paling tinggi, diikuti oleh beras hitam utuh dan mesh 20/40. Serbuk beras hitam ukuran partikel mesh 20/40 memiliki kandungan antosianin yang paling kecil pada hasil maserasinya karena dalam 100 gram serbuk lebih banyak mengandung amilum daripada antosianinnya.

Ukuran partikel simplisia yang berbedabeda memiliki luas permukaan kontak yang berbeda-beda pula. Luas permukaan kontak simplisia yang berbeda akan menyebabkan jumlah antosianin yang tersari berbeda. Kontak yang luas antara simplisia dan pelarut akan memberikan kesempatan yang lebih besar dalam mengekstrasi antosianin. Antosianin akan tersari lebih banyak jika pelarut mampu kontak lebih luas dengan simplisia. Jumlah antosianin yang tersari ditunjukkan oleh rendemen ekstrak dan kandungan total antosianin. Rendemen ekstrak adalah perbandingan bobot ekstrak antosianin dengan bobot simplisia.

Rendemen ekstrak adalah perbandingan bobot ekstrak antosianin dengan bobot simplisia. Rendemen ekstrak yang tinggi menunjukkan bahwa jumlah antosianin yang tersari dari simplisia tinggi. Penetapan kandungan total antosianin pada ekstrak beras hitam juga menunjukkan bahwa ekstrak dengan rendemen yang tinggi memiliki kadar antosianin yang tinggi. Dengan demikian, hasil penelitian ini menunjukkan bahwa ukuran partikel beras hitam berpengaruh terhadap rendemen ekstrak dan kandungan total antosianin hasil maserasi. 


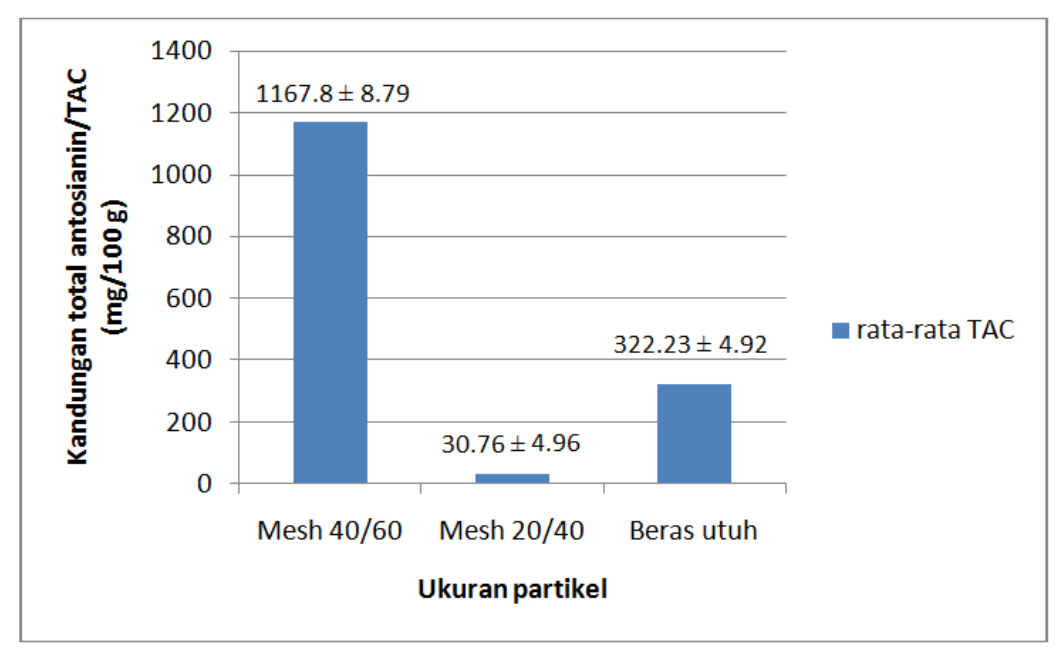

Gambar 3. Nilai rata-rata kandungan total antosianin ekstrak beras hitam dengan berbagai ukuran partikel

\section{KESIMPULAN}

Perbedaan ukuran partikel beras hitam (Oryza sativa L.) berpengaruh terhadap rendemen ekstrak dan kandungan total antosianin hasil maserasi.

\section{DAFTAR PUSTAKA}

Bangee, O.D., Wilson, V. H., East, G. C., Holme, I., 1995, Antioxidant-induced Yellowing of Textiles, Polymer Degradation and Stability, 50 (3) : 313-317.

Bondre, Sushma., Patil, Pallavi., Kulkarni, Amaraja., Pillai, M. M. ., 2012, Study on Isolation and Purification of Anthocyanins and Its Application as $\mathrm{pH}$ Indicator, International Journal of Advanced Biotechnology and Research, 3(3): 698-702.

Harborne, J. B., 1987, Metode Fitokimia: Penuntun Cara Modern Menganalisis Tumbuhan, Bandung: Penerbit ITB.

Heath, H.B and eineccius, G. 1986. Flavor Chemistry and Technology.AVI Publ. co. Inc.,Westport, Connecticut.

Jones, E. G., Balster, Walter J., Balster, Lori M., 1997, Aviation Fuel Recirculation and Surface Fouling, Energy \& Fuels, 11(6) 1303-1308.
Kamei, H., Kojima, T., Hasegawa, M., Kiode, T. Umeda, T., Yukawa, T., Terabe, K., 1995, Suppression of Tumor Cell Growth by Anthocyanin in Vitro, Cancer Invest, 13: 590-594.

Karaivanova, M., Denska, D., and Ovcharov, R., 1990, A Modification of the Toxic Effect of Platinum Complexes with Anthocyanin, Eksperimentalna meditsina morfologiia, 29: 19-24.

Kristamtini, Taryono, Basunanda, Panjisakti., Murti, Rudi Hari., 2014, Keragaman Genetik dan Korelasi Parameter Warna Beras dan Kandungan Antosianin Total Sebelas Kultivar Padi Beras Hitam Lokal, Ilmu Pertanian 17(1): 57-70.

Kumalaningsih, Sri, 2007, Antioksidan Alami, Surabaya: Trubus Agrisarana.

Martin, Alfred., Swarbrick, James., Cammarata, Athur., 1993, Farmasi Fisik: Dasardasar Kimia Fisik dalam Ilmu Farmasi. Jakarta: UI-PRESS.

Pan, Jiang-Qing., Liu, N. C., Wayne, W. Y., Lau, 1998, Preparation and Properties of New Antioxidants with Higher MW, Polymer Degradation and Stability, 62(1): 165-170. 
Purseglove, J. W., 1981, Spices Vol. II, New York: Longman Inc.

Pushpa, S. A., P., Goonetellike., N. C., Billingham, 1995, Diffusion of Antioxidants in Rubber, Rubber Chemistry and Technology, 65(5): 705716.

Robinson, T, 1995, Kandungan Organik Tumbuhan Tinggi, Bandung: Penerbit ITB.

Suzery, M., Lestari, S., Cahyono, B., 2010, Penentuan Total Antosianin dari Kelopak Buga Rosella (Hibiscus sabdariffa L.) dengan Metode Maserasi dan Soxhletasi, Jurnal Sains dan Matematika (JSM), 18(1): 1-6.
Thompson, Stephen., 1989, Chemtrek: Smallscale Experiments for General Chemistry, New Jersey: Prentice Hall, Inc.

Voigt, R., 1995, Buku Pelajaran Teknologi Farmasi, Yogyakarta: Gadja Mada University Press.

Wrolstad, Ronald E., Giusti, M. Monica., 2001, Characterization and Measurement of Anthocyanins by UV-Vis Sepctroscopy, Current Protocols in Food Analytical Chemistry, F1.2.1-F1.2.13.

Yoshimura, Yukihiro.,Zaima, Nobuhiro., Moriyama, Tatsuya., Yawamura, Yukio., 2012, Different Localization Patterns of Anthocyanin Species in the Pericarp of Black Rice Revealed by Imaging Mass Spectrometry. PLoS ONE, 7(2): 1-9. 